\title{
CIGS2 THIN-FILM SOLAR CELLS ON FLEXIBLE FOILS FOR SPACE POWER ${ }^{1}$
}

\author{
Neelkanth G. Dhere, Shantinath R. Ghongadi, Mandar B. Pandit, Anant H. Jahagirdar \\ Florida Solar Energy Center, 1679 Clearlake Road, Cocoa, FL 32922-5703 \\ David Scheiman \\ Ohio Aerospace Institute, NASA Glenn Research Center, Cleveland, Ohio 44135
}

\begin{abstract}
Culn $_{1-x} G_{x} S_{2}$ (CIGS2) thin-film solar cells are of interest for space power applications because of the near optimum bandgap for AMO solar radiation in space. CIGS2 thin film solar cells on flexible stainless steel (SS) may be able to increase the specific power by an order of magnitude from the current level of $65 \mathrm{Wkg}^{-1}$. CIGS solar cells are superior to the conventional silicon and gallium arsenide solar cells in the space radiation environment. This paper presents research efforts for the development of CIGS2 thin-film solar cells on 127 $\mu \mathrm{m}$ and $20 \mu \mathrm{m}$ thick, bright-annealed flexible SS foil for space power. A large-area, dual-chamber, inline thin film deposition system has been fabricated. The system is expected to provide thickness uniformity of $\pm 2 \%$ over the central 5 " width and $\pm 3 \%$ over the central 6 " width. During the next phase, facilities for processing larger cells will be acquired for selenization and sulfurization of metallic precursors and for heterojunction CdS layer deposition both on large area. Small area CIGS2 thin film solar cells are being prepared routinely. Curich Cu-Ga/In layers were sputter-deposited on unheated Mo-coated SS foils from CuGa (22\%) and In targets. Well-adherent, large-grain Cu-rich CIGS2 films were obtained by sulfurization in a $\mathrm{Ar}$ : $\mathrm{H}_{2} \mathrm{~S}$ 1:0.04 mixture and argon flow rate of $650 \mathrm{sccm}$, at the maximum temperature of $475^{\circ} \mathrm{C}$ for 60 minutes with intermediate 30 minutes annealing step at $120^{\circ} \mathrm{C}$. Samples were annealed at $500^{\circ} \mathrm{C}$ for 10 minutes without $\mathrm{H}_{2} \mathrm{~S}$ gas flow. The intermediate 30 minutes annealing step at $120^{\circ} \mathrm{C}$ was changed to $135^{\circ} \mathrm{C}$. p-type $\mathrm{CIGS} 2$ thin films were obtained by etching the $\mathrm{Cu}$-rich layer segregated at the surface using dilute $\mathrm{KCN}$ solution. Solar cells were completed by deposition of CdS heterojunction partner layer by chemical bath deposition, transparent-conducting $\mathrm{ZnO} / \mathrm{ZnO}$ : Al window bilayer by RF sputtering, and vacuum deposition of Ni/Al contact fingers through metal mask. PV parameters of a CIGS2 solar cell on $127 \mu \mathrm{m}$ thick SS flexible foil measured under AM 0 conditions at NASA GRC were: $V_{o c}=802.9 \mathrm{mV}, \mathrm{J}_{\mathrm{sc}}=25.07 \mathrm{~mA} / \mathrm{cm}^{2}, \mathrm{FF}=60.06 \%$, and efficiency $0=8.84 \%$. For this cell, AM 1.5 PV parameters measured at NREL were: $V_{o c}=788 \mathrm{mV}, J_{\mathrm{sc}}=19.78 \mathrm{~mA} / \mathrm{cm}^{2}$, $\mathrm{FF}=59.44 \%$, efficiency $0=9.26 \%$. Quantum efficiency curve showed a sharp QE cutoff equivalent to CIGS2 bandgap of $\sim 1.50 \mathrm{eV}$, fairly close to the optimum value for efficient AMO PV conversion in the space.
\end{abstract}

\section{INTRODUCTION}

Lightweight flexible thin film solar cells have many promising applications in space and terrestrial photovoltaic power systems [1]. Future space missions would include very large satellites such as solar power satellites and very small satellites. Long-term plans envisage swarms of distributed, autonomous, small satellites termed microsats or even nanosats to perform specific tasks. Some missions will use solar electric propulsion (SEP) instead of rockets. CIGS2 thin film solar cells on flexible stainless steel (SS) may be able to increase the specific power by an order of magnitude from the current level of $65 \mathrm{Wkg}^{-1}$. Thin-film technology could conservatively reduce the array-manufacturing cost of medium-sized five-kilowatt satellite from the current level of $\$ 2000 \mathrm{k}$ to less than $\$ 500 \mathrm{k}$ [2]. Weight benefits of higher efficiency cells are decreased and high costs become less affordable in the case of flexible thin-film blanket arrays that can be easily rolled out. Non-rigid cells also have an advantage in stability. Because of the low initial velocities and steady acceleration, SEP satellites must spend long periods in intense regions of trapped radiation belts. CIGS solar cells are superior to the conventional silicon and gallium arsenide solar cells in the space radiation

\footnotetext{
${ }^{1}$ This work was supported by the NASA Glenn Research Center and by the Air Force Research Lab through Jackson and Tull.
} 
environment. The potential for improved radiation resistance of thin-film solar cells relative to single-crystal cells, could extend mission lifetimes substantially. Recent studies have shown that $12.6 \%$ efficient, thin film cells would start to become cost-competitive in GEO and LEO missions [3]. However, significant technological hurdles remain before thin-film technology could be implemented as the primary power source for spacecraft.

There is a recent interest in the development of CIGS2 solar cells on flexible substrates. Several groups have reported fabrication of polycrystalline $\mathrm{Culn}_{1-x} \mathrm{Ga}_{x} \mathrm{Se}_{2}$ (CIGS) solar cells on flexible foils substrates [4]. The CIGS cell with an efficiency exceeding $17 \%$ has been obtained using SS substrate [4].

The objective of the present research is to develop ultra-lightweight, radiation-resistant, highly efficient, high specific power Culn ${ }_{1-x} \mathrm{Ga}_{x} \mathrm{~S}_{2}$ (CIGS2) thin-film solar cells for space electric power. Small proportion of gallium is being incorporated so as to obtain benefits of improved adhesion, slightly higher bandgap, and incorporation of back-surface field as has been done with CIGS cells. Initially CIGS2 thin film solar cells are being fabricated on $127 \mu \mathrm{m}$ thick SS substrates. The main thrust is towards development of fundamental understanding and baseline processes rather than attaining the highest efficiencies.

\section{EXPERIMENTAL TECHNIQUE}

Bright annealed stainless steel foils with thickness of $127 \mu \mathrm{m}$ and $20 \mu \mathrm{m}$ were used as substrate. Copper, gallium and indium layers were sputtered in the ratio of $\mathrm{Cu} /(\mathrm{In}+\mathrm{Ga}) \sim 1.4$. ClGS2 thin films were prepared using a two-step process. The first step involved deposition of alternate layers of $(\mathrm{Cu}+\mathrm{Ga})$ and In on molybdenum coated flexible substrate. This formed a stacked elemental layer sequence that produced a predominant $\mathrm{Cu}_{11} \mid \mathbf{n}_{9}$ precursor phase. This layer was sulfurized in $\mathrm{H}_{2} \mathrm{~S}$ : Ar gas environment using a three zone furnace at temperatures in the range of 135 to $475^{\circ} \mathrm{C}$. Sulfurization time was varied from $20-60$ minutes. Samples were annealed at $500^{\circ} \mathrm{C}$ for 10 minutes without $\mathrm{H}_{2} \mathrm{~S}$ gas flow in $\mathrm{Ar}$ atmosphere. The initial dwell of $120^{\circ} \mathrm{C}$ for 30 minutes was changed to $135^{\circ} \mathrm{C}$ for 25 minutes without $\mathrm{H}_{2} \mathrm{~S}$ gas flow during sulfurization. It was found that the binary $\mathrm{Cu}_{11} \mathrm{In}_{9}$ precursor phase reacted in $\mathrm{H}_{2} \mathrm{~S}$ : Ar gas environment to form a good crystalline pseudo-quaternary phase of CIGS2 film. Some samples were sulfurized at $475^{\circ} \mathrm{C}$ for 30 minutes followed by annealing at $500^{\circ} \mathrm{C}$ for 10 minutes. This annealing step favored grain growth and recrystallization. The Cu-rich stoichiometry during the growth of CIGS2 films results in an improved morphology, i.e. enhanced grain sizes of the polycrystalline films. For selenide system, this phenomenon is attributed to CuSe liquid formed on top of Cu-rich films [5]. For the sulfur system, according to the phase diagram of Cu-S, the respective liquid phase is not expected in the substrate temperature range of $\mathrm{T}_{\text {sub }}<600^{\circ}$ C. However, due to the high cation mobility in the Cu-S compounds, the cation lattice in a binary Cu-S phase at the surface of a growing CIS2 film behaves as a quasi-liquid. The $\mathrm{Cu}_{\mathrm{x}} \mathrm{S}$ phase was etched using $10 \% \mathrm{KCN}$. This was followed by deposition of CdS buffer layer by chemical bath method and ZnO window layer (Fig.1). Bright annealed stainless steel foils of 20 and $127 \mu \mathrm{m}$ thickness respectively were evaluated as possible substrate materials for polycrystalline CIGS2 solar cell. The phases, surface morphologies and elemental depth profiles of the CIGS2 films prepared on stainless steel flexible foils substrates were characterized.

Films were examined visually for their appearance, color and any tendency of peeling. $X$-ray diffraction (XRD) was used to identify the crystalline phases using a RIGAKU diffractometer. The 20 range for the diffractometer was set from 10 to $80^{\circ}$ with a step size of $0.02^{\circ}$. Surface morphology study of the CIGS2 thin film was performed using Scanning electron microscopy (SEM). Chemical composition was analyzed by employing electron probe microanalysis (EPMA). Depth profiling was performed using secondary ion mass spectroscopy (SIMS) and Auger electron spectroscopy (AES) with simultaneous sputter etching. The substrate surface roughness was measured using DEKTAK ${ }^{3}$ surface profile measuring system.

\begin{tabular}{|c|}
\multicolumn{1}{c}{ Ni-Al Grid } \\
\hline n-type ZnO:Al $(0.50 \mu \mathrm{m})$ \\
\hline n-type CdS $(0.05 \mu \mathrm{m})$ \\
\hline p-type CIGS2 $(2.75 \mu \mathrm{m})$ \\
\hline Molybdenum $(0.55 \mu \mathrm{m})$ \\
\hline Metallic Substrate $(127 \mu \mathrm{m} / 20 \mu \mathrm{m})$ \\
\hline
\end{tabular}

Figure 1. Layer sequence of CIGS2 thin film solar cell. 


\section{RESULTS AND DISCUSSION}

To avoid the formation of voids before the initiation of sulfurization, the initial dwell of 30 minutes at $120^{\circ} \mathrm{C}$ was changed to $135^{\circ} \mathrm{C}$, and the flow of $\mathrm{H}_{2} \mathrm{~S}$ gas was started after 25 minutes at $135^{\circ} \mathrm{C}$ [6]. The X-ray diffraction spectrum of the as-deposited $(\mathrm{Cu}+\mathrm{Ga}) / \mathrm{ln}$ metallic precursors processed at $135^{\circ} \mathrm{C}$ indicated the presence of highly oriented $\mathrm{Cu}_{11} \mathrm{In}_{9}$ phase without any elemental or alloy phases. Figure 2 is the XRD pattern of a near stoichiometric, slightly Cu-poor, etched CIGS2 thin film. It showed (101), (112), (103), (004)/(200), (213), (204)/(200), (116)/(312), (008)/(400), and (332) reflections of Culn $\mathrm{n}_{0.7} \mathrm{Ga}_{0.3} \mathrm{~S}_{2}$ phase. The strongest reflection was from (112) set of planes at $27.62^{\circ}$. Mo peak was obtained $40.22^{\circ}$. The lattice parameters calculated were a $5.67 \AA$ and c $11.34 \AA$. The spectra stayed well above the base line in between the (112) Culns2 and the (112) CuGas2 maxima indicating the pseudo-quaternary phase with varying $\mathrm{Ga} /(\mathrm{In}+\mathrm{Ga})$ ratio. Ga diffused towards Mo back contact creating a compositional gradient that resulted in a localized Ga poor phase on the surface and in the bulk of material and $\mathrm{Ga}$ rich phase near back contact in polycrystalline CIGS2 thin film [7]. Because of the compositional gradient in $\mathrm{Ga}$ content with $\mathrm{Ga} /(\mathrm{Ga}+\mathrm{In})$ ratio of 0.13 at the surface and 0.23 near the back contact, peaks were broad at the base line of the spectra showing reflection from (112) set of planes with $\mathrm{Ga}$ poor phase on the surface. In case of random orientation, the intensity ratio of (112) with respect to (220)/(204) peaks, should be 1.5 . The intensity ratio of $I_{112} / I_{220 / 204}$, for these films, was remarkably very high, showing a very high degree of preferred orientation towards (112) reflection that was beneficial for good lattice matching with $\mathrm{CdS}$ for efficient device fabrication.

Despite the very Cu-rich film of unetched sample with $\mathrm{Cu} /(\mathrm{In}+\mathrm{Ga})$ ratio up to 1.68 no secondary phases could be detected in the XRD pattern for unetched sample [8]. As discussed earlier a Cu-rich stoichiometry during the growth of CIGS2 films results in an improved morphology, i.e. enhanced grain sizes of the polycrystalline films. This excess $\mathrm{Cu}_{x} \mathrm{~S}$ was etched using $10 \% \mathrm{KCN}$.

The surface scanning electron micrograph (SEM) of a near stoichiometric, slightly Cu-poor, etched CIGS2 thin film is shown in figure 3. SEM image for the sample showed large, well faceted grains with slight porosity. The porosity was observed at the grain boundaries from where the $\mathrm{Cu}_{\mathrm{x}} \mathrm{S}$ phases have been etched. The grain size measured by intercept method was $3 \mu \mathrm{m}$ i.e. comparable to film thickness.

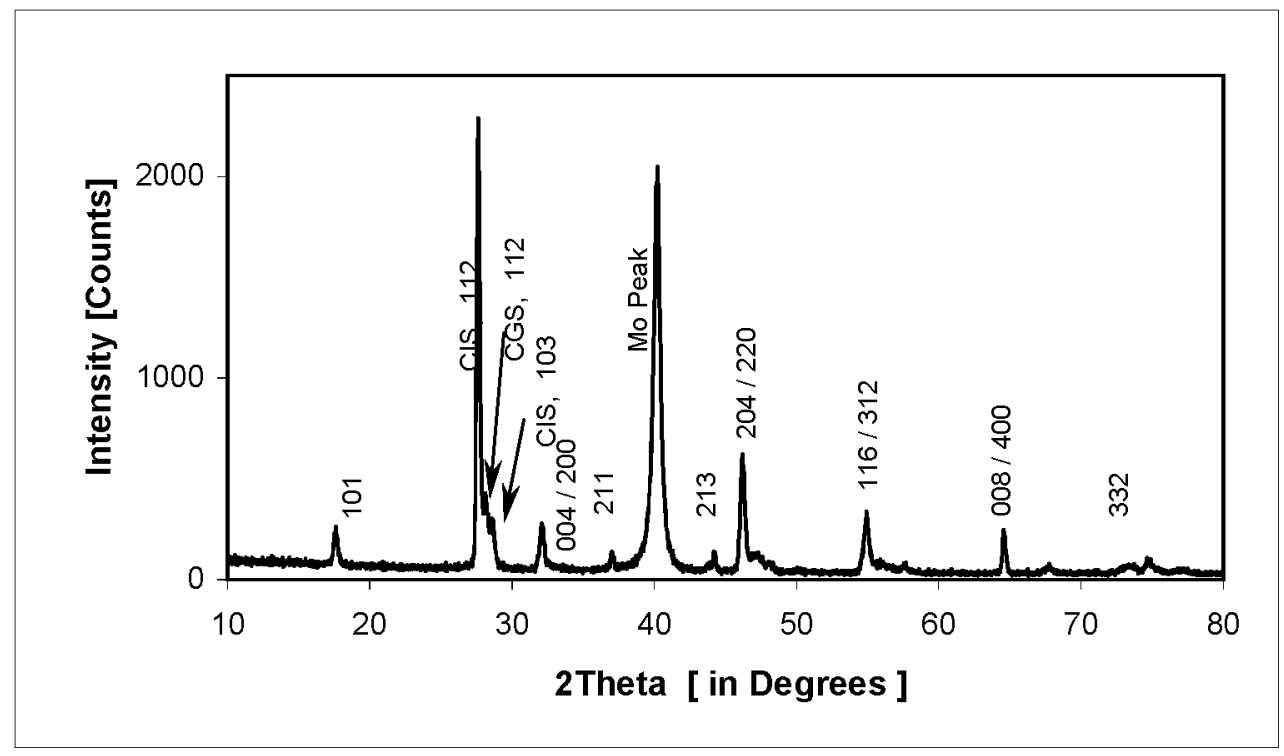

Figure 2. XRD pattern from a near stoichiometric, slightly Cu-poor, etched CIGS2 thin film. 


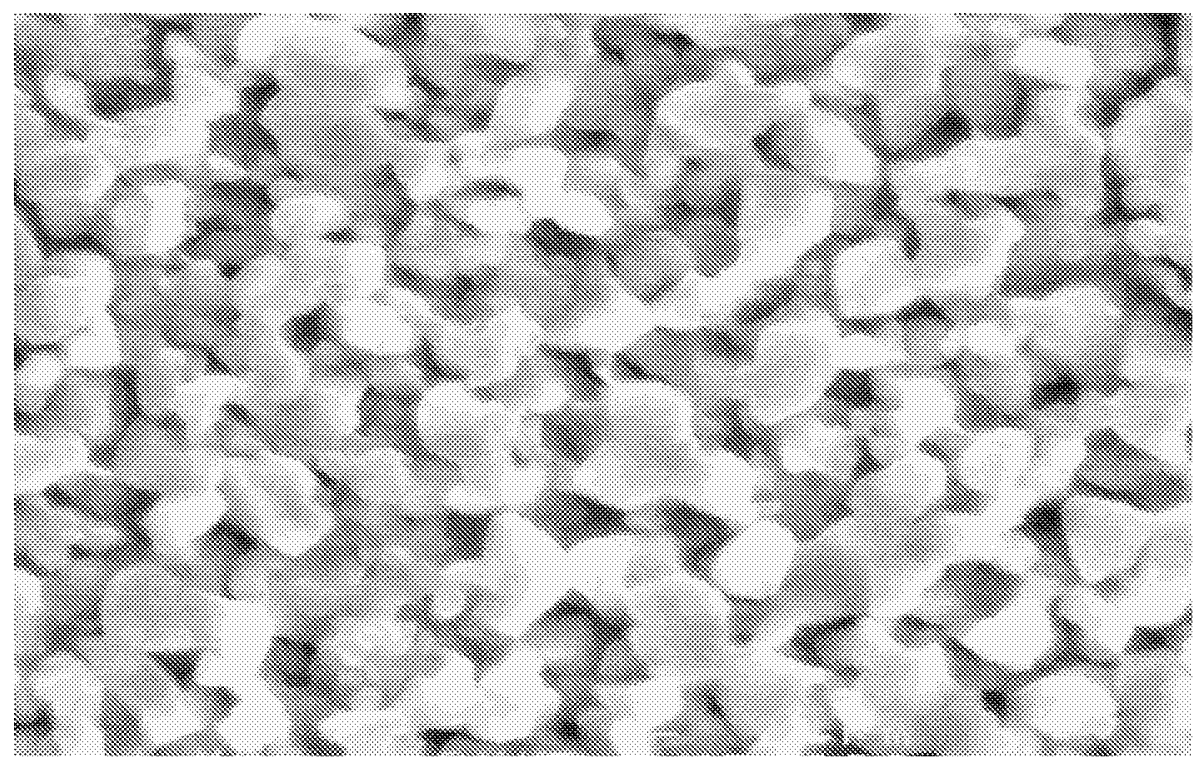

Figure 3. Surface SEM image of a near stoichiometric, slightly Cu-poor, etched CIGS2 thin film.

AES survey (Fig. 4) of near stoichiometric, slightly Cu-poor, etched CIGS2 thin film sample was performed over a range of kinetic energies of $50-2250 \mathrm{eV}$. The primary electron beam having energy of $5 \mathrm{keV}$ was made incident on the sample surface for analysis. A representative area of sample was chosen and an AES survey was carried out at magnification of $1000 \times$ equivalent to an area of $102 \mu \mathrm{m} \times 102 \mu \mathrm{m}$. An AES survey over the selected area showed presence of copper at $60,777,850$, and $924 \mathrm{eV}$, sulfur at 151 , and $2131 \mathrm{eV}$, indium at 345 , and $410 \mathrm{eV}$, gallium at $1071 \mathrm{eV}$, carbon at $273 \mathrm{eV}$, potassium at $252 \mathrm{eV}$ and oxygen at $515 \mathrm{eV}$. The surface atomic concentrations calculated by using the peak-to-peak height from AES survey and relative sensitivities of the respective elements were as follows: copper 20.67 atomic (at.) \%, sulfur 31.62 at. \%, indium 12.63 at. $\%$, gallium 6.92 at. \%, potassium 7.72 at. \%, oxygen 11.92 at. \% and carbon 15.04 at. $\%$.

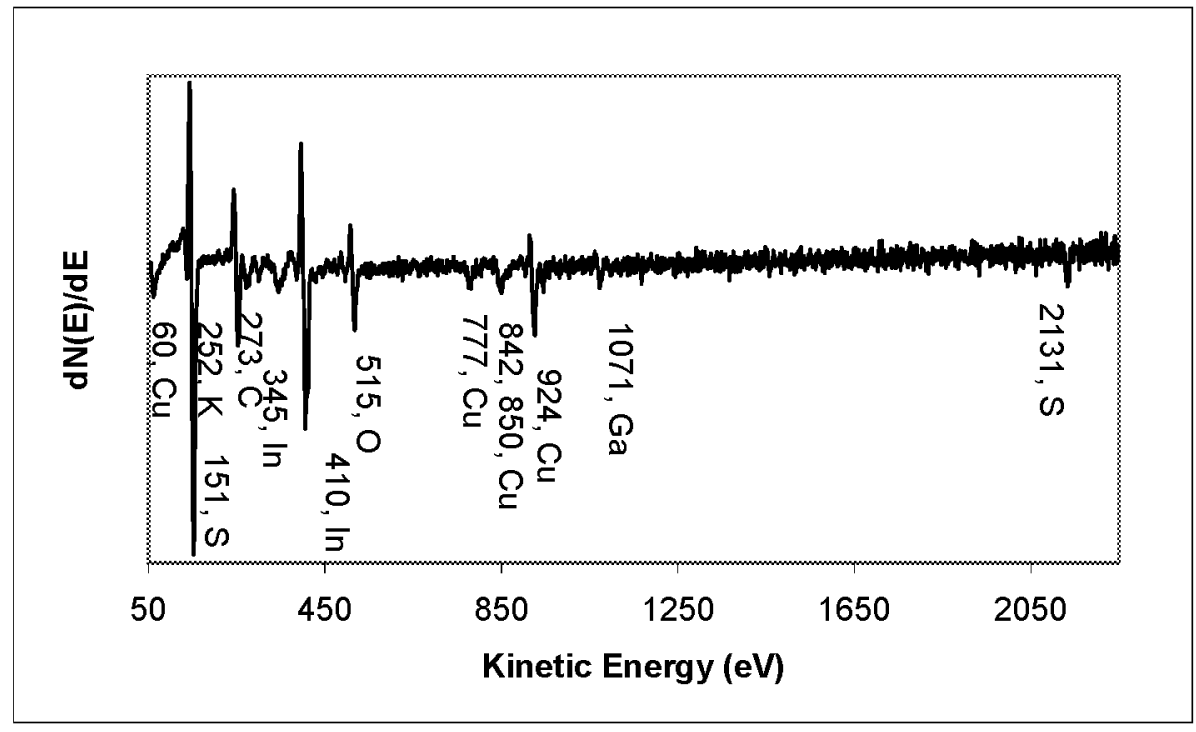

Figure 4. Surface AES survey of near stoichiometric, slightly Cu-poor, etched CIGS2 thin film. 


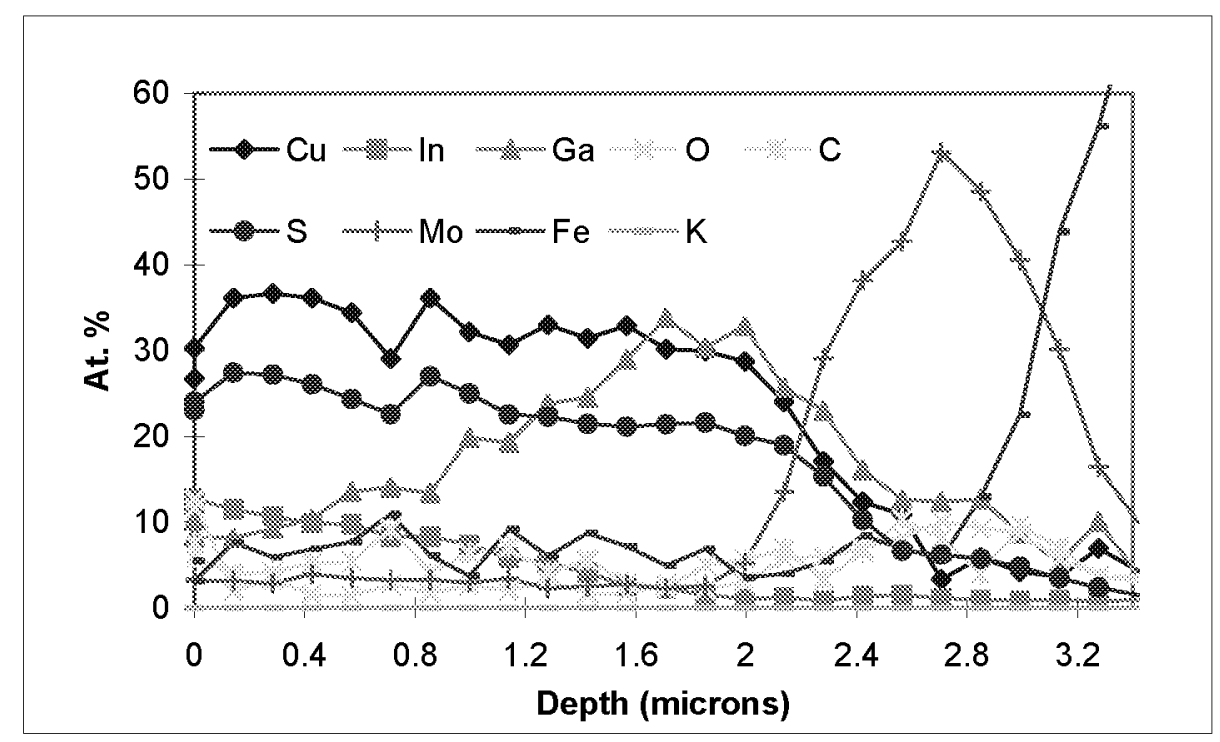

Figure 5. AES depth profile of near stoichiometric, slightly Cu-poor, etched CIGS2 thin film.

AES depth profile was obtained by sputtering an area of $1 \times 1 \mathrm{~mm}^{2}$ with energetic argon ions at a rate of $475 \AA$ min for 72 minutes. Figure 5 shows peak heights at different depths (time) for different element. The peak heights were obtained for the following elements: copper, indium, gallium, oxygen, carbon, sulfur, molybdenum, iron and potassium. Copper and sulfur concentration showed the same trend. It decreased near the Mo back contact. . Potassium was detected at the surface. Its concentration decreased rapidly in the bulk. Potassium was attributed to $\mathrm{KCN}$ treatment that was used to etch away excess $\mathrm{Cu}_{\mathrm{x}} \mathrm{S}$ phase. Indium concentration is constant in most of the thickness of CIGS2 layer and falls near the Mo back contact. Concentration of gallium at the surface was approximately $10 \%$ while at the CIGS/Mo interface it was $30 \%$. This showed that $\mathrm{Ga}$ concentration increased towards the back Mo contact. Indium concentration decreased with depth and was negligible at CIGS/Mo interface. The apparent humps in the depth profiles are caused by a non-uniform sputter-etching rate. It can be seen that the film thickness of etched CIGS2 sample from depth profile was approximately $2.4 \mu \mathrm{m}$.

SIMS depth profiling (Fig.6) was performed on an etched samples by positive SIMS using CAMECA IMS - 3F system with oxygen primary beam current of $150 \mathrm{nA}$, impact energy of $5.5 \mathrm{keV}$ angle of incidence of $42^{\circ}$, rastered over $250 \mu \mathrm{m} \times 250 \mu \mathrm{m}$ area, with source at $10 \mathrm{keV}$ and sample at $4.5 \mathrm{keV}$. The corresponding unetched sample had $\mathrm{Cu} /(\mathrm{In}+\mathrm{Ga}) \sim 1.4$ and was sulfurized at $475^{\circ} \mathrm{C}$ for 30 minutes and annealed for 10 minutes each at 475 and $500^{\circ} \mathrm{C}$ respectively. Slightly Cu-poor, etched CIGS2 thin film sample was monitored for eight species. To realize high sensitivity measurements secondary positive cluster ions such as ${ }^{23} \mathrm{Na},{ }^{34} \mathrm{~S}$, $\mathrm{K},{ }^{54} \mathrm{Fe},{ }^{65} \mathrm{Cu},{ }^{69}(\mathrm{Ga}+\mathrm{O}),{ }^{92} \mathrm{Mo}$, and ${ }^{113}(\mathrm{In}+\mathrm{O})$ were used for detection of $\mathrm{Na}, \mathrm{S}, \mathrm{K}, \mathrm{Fe}, \mathrm{Cu}, \mathrm{Ga}$, Mo, and In respectively. Cu concentration was mostly constant over the depth of the film. Ga concentration remained constant till $1 \mu \mathrm{m}$ and then increased till the Mo back contact. Indium concentration remained constant through most of film thickness and decreased near the Mo back contact. Na was not added intentionally. $S$ concentration was uniform throughout film thickness. Na concentration at surface of substrate was attributed to residue left due to cleaning with soap solution. Potassium incorporation was due to etching of $\mathrm{Cu}_{\mathrm{x}} \mathrm{S}$ phase present on the grains and near the grain boundaries with $\mathrm{KCN}$ solution. No sharp interfaces were observed at CIGS2/Mo and Mo/Substrate respectively. This was probably because of the interdiffusion of species and porosity formed due to etching with $10 \% \mathrm{KCN}$ treatment. 


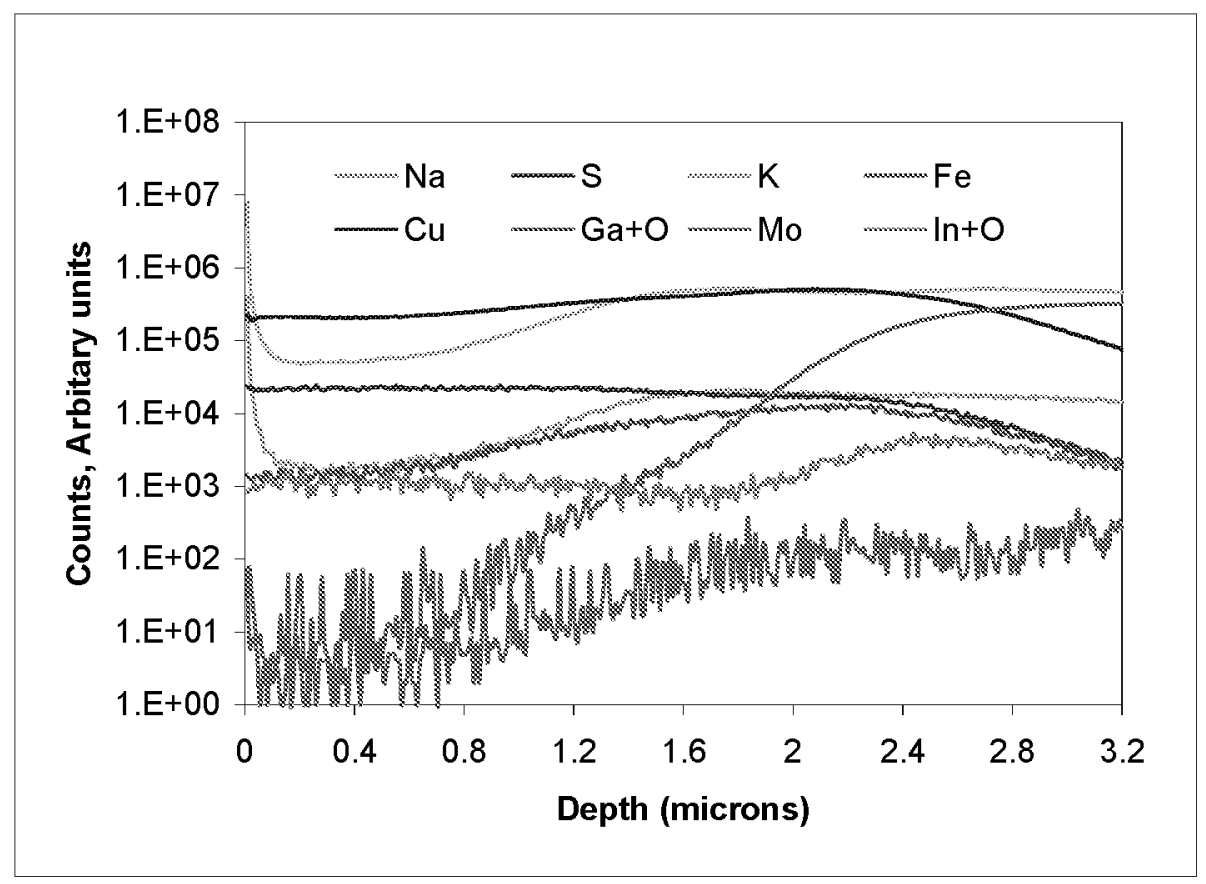

Figure 6. SIMS depth profile of near stoichiometric, slightly Cu-poor, etched CIGS2 thin film.

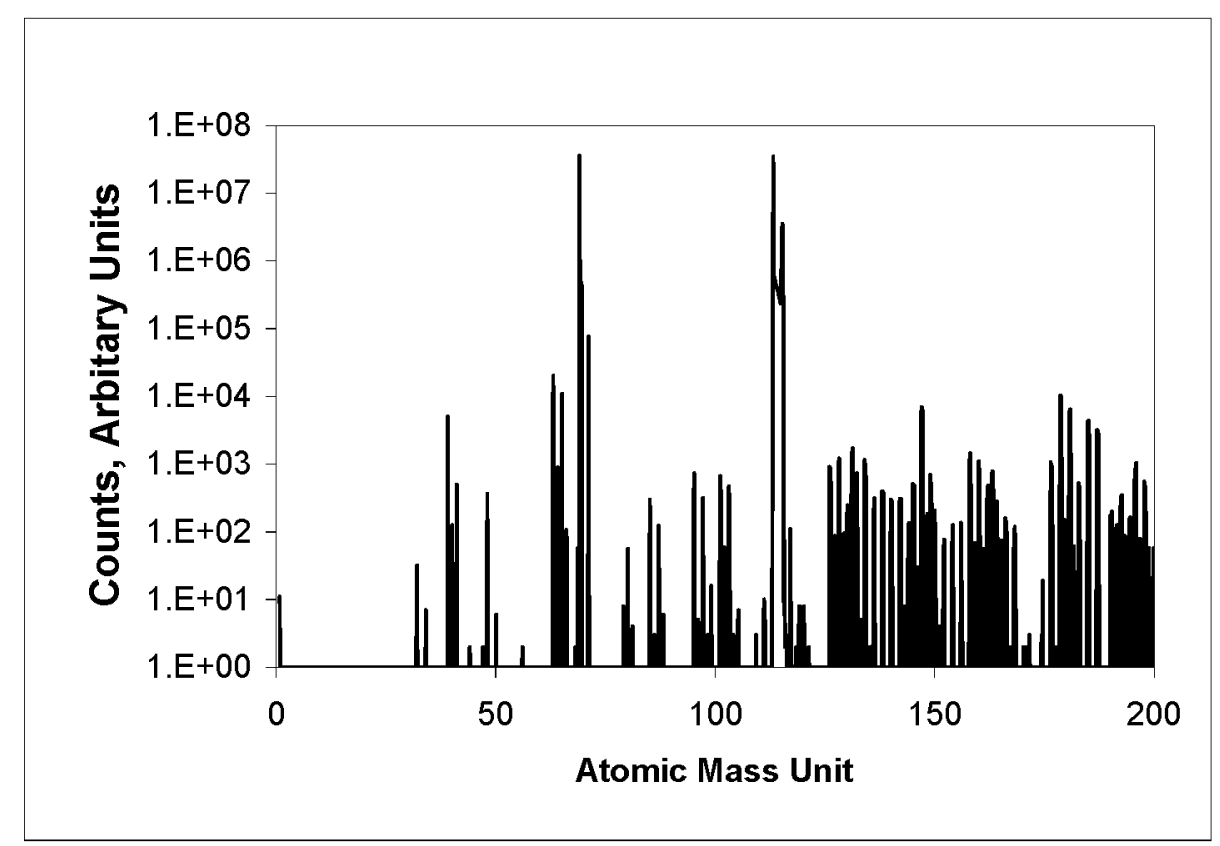

Figure 7. SIMS mass spectra of near stoichiometric, slightly Cu-poor, etched CIGS2 thin film. 
The mass spectrum recorded from masses of 1 to 200 is shown in figure 7 . Sharp peaks were observed for elemental and molecular species such as $\mathrm{O}_{2}^{+}, \mathrm{S}^{+}, \mathrm{K}^{+}, \mathrm{Ca}^{+}, \mathrm{SO}^{+}, \mathrm{Cu}^{+}, \mathrm{Ga}^{+}, \mathrm{GaO}^{+}, \mathrm{CuO}^{+}, \mathrm{CuO}^{++}$, $\mathrm{In}^{+}, \mathrm{InO}^{+}$, and $\mathrm{InO}_{2}{ }^{+}$. Na was not detected during analysis of mass spectra. Because of large number of isotopes of $\mathrm{Cu}, \mathrm{In}, \mathrm{Mo}, \mathrm{Ga}$, and $\mathrm{S}$, a number of mass interferences were observed. The mass spectrum clearly indicated presence of $\mathrm{Cu}, \mathrm{In}, \mathrm{Ga}, \mathrm{S}, \mathrm{Mo}$ and $\mathrm{K}$.

The chemical composition of CIGS2 films was analyzed by EPMA. Average atomic concentrations measured at $10 \mathrm{KV}$ and $20 \mathrm{KV}$ for an unetched sample showed $\mathrm{Cu}: \operatorname{In}: \mathrm{Ga}$ : S proportion of 51.52: 7.80: 1.83: 38.83 and 41.90: 10.92: 2.56: 44.63 respectively. The $\mathrm{Cu}: \mathrm{In}: \mathrm{Ga}: \mathrm{S}$ atomic concentrations for the etched sample at $10 \mathrm{KV}$ and $20 \mathrm{KV}$ were found to be 27.38: 21.61: 3.30: 47.71 and 23.96: 19.36: 5.70: 50.99 respectively. The compound formulae were $\mathrm{Cu}_{1.09} \mathrm{In}_{0.87} \mathrm{Ga}_{0.13} \mathrm{~S}_{2}$ and $\mathrm{Cu}_{0.96} \mathbf{n}_{0.77} \mathrm{Ga}_{0.23} \mathrm{~S}_{2}$ respectively. The $\mathrm{Cu}$ : In: Ga: $S$ atomic concentrations for the etched sample deposited on $20 \mu \mathrm{m}$ thick SS foil at $20 \mathrm{KV}$ were found to be 28.60: 14.90: 11.42: 45.10. The compound formula was $\mathrm{Cu}_{1.10} \mathrm{In}_{0.60} \mathrm{Ga}_{0.40} \mathrm{~S}_{2}$.

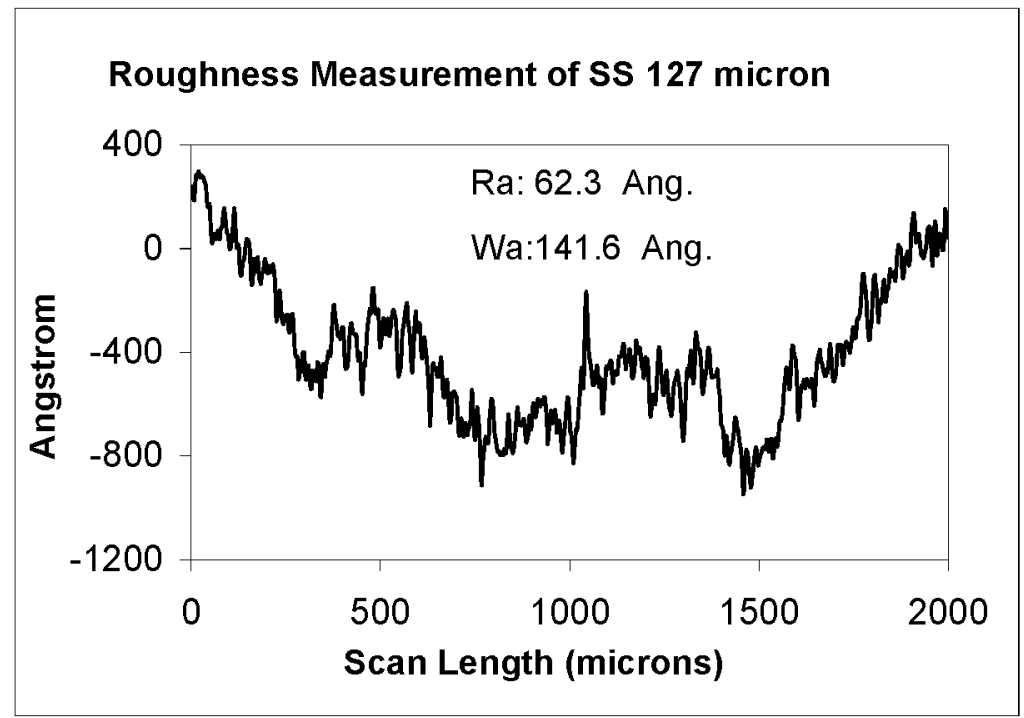

Figure 8. Surface roughness measurement of $127 \mu \mathrm{m}$ thick SS foil.

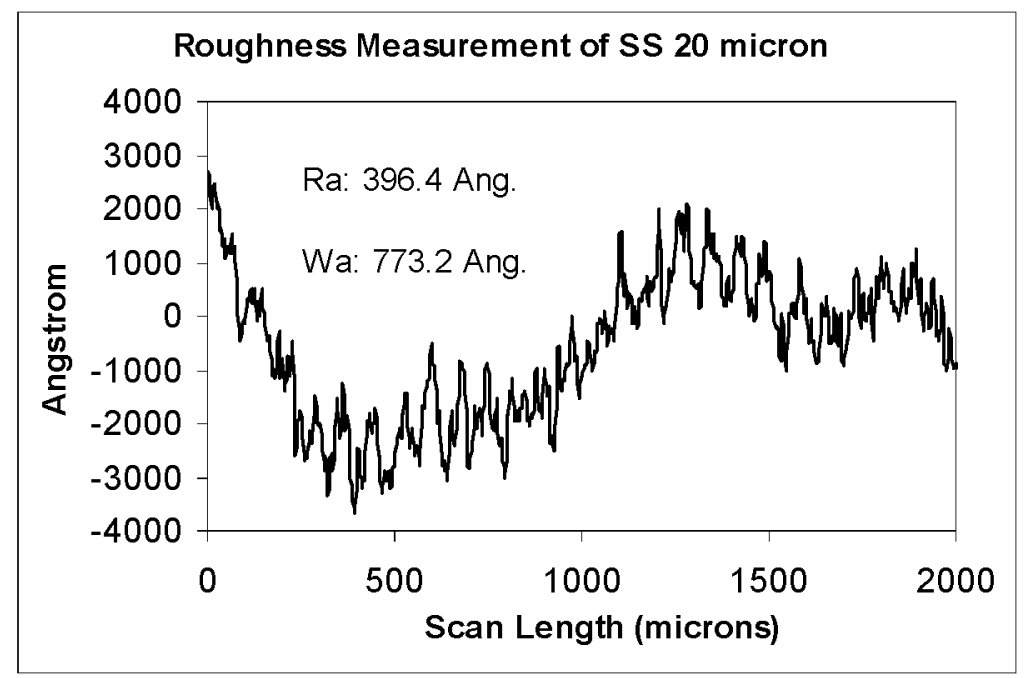

Figure 9. Surface roughness measurement of $20 \mu \mathrm{m}$ thick SS foil. 
Table I. Projected Specific Power in W/Kg.

\begin{tabular}{|c|c|c|}
\hline \multirow{2}{*}{ Substrate } & \multicolumn{2}{|c|}{ Projected Specific Power in W/Kg. } \\
\cline { 2 - 3 } & For $\eta=10 \%$ at AM 0. & For $\eta=15 \%$ at AM 0. \\
\hline $127-\mu \mathrm{m}(5$ mil) SS foil & 133.03 & 199.55 \\
\hline $20-\mu \mathrm{m}(<1 \mathrm{mil})$ SS foil & 768.75 & 1153.13 \\
\hline $25.4-\mu \mathrm{m}(1 \mathrm{mil})$ Ti foil & 1015.76 & 1523.64 \\
\hline
\end{tabular}

Surface roughness of the substrate was measured using DEKTAK ${ }^{3}$ surface profile measuring system. The average roughness (Ra) value measured of $127 \mu \mathrm{m}$ thick SS foil (Fig. 8) was $62.3 \AA$ and average waviness (Wa) was 141.6 A. The average roughness (Ra) value measured of $20 \mu \mathrm{m}$ thick SS foil (Fig. 9) was 396.4 $\AA$ and surface waviness $(\mathrm{Wa})$ was $773.2 \AA$.

PV parameters of a CIGS2 solar cell on $127 \mu \mathrm{m}$ thick SS flexible foil measured under AM 0 (Fig.10) conditions at the NASA GRC were: $\mathrm{V}_{\mathrm{oc}}=802.9 \mathrm{mV}, \mathrm{J}_{\mathrm{sc}}=25.07 \mathrm{~mA} / \mathrm{cm}^{2}, \mathrm{FF}=60.06 \%$, and $0=8.84 \%$. For this cell, AM 1.5 PV parameters measured at NREL were: $\mathrm{V}_{\mathrm{oc}}=788 \mathrm{mV}, \mathrm{J}_{\mathrm{sc}}=19.78 \mathrm{~mA} / \mathrm{cm}^{2}, \mathrm{FF}=59.44 \%, 0$ $=9.26 \%$. Quantum efficiency curve (Fig.11) showed a sharp QE cutoff equivalent to CIGS2 bandgap of $\sim 1.50 \mathrm{eV}$, fairly close to the optimum value for efficient AMO PV conversion in the space. PV parameters for cell fabricated on $20 \mu \mathrm{m}$ thick SS foil measured at NREL under AM 1.5 conditions were: $\mathrm{Voc}=740 \mathrm{mV}$, Jsc $=$ $13.129 \mathrm{~mA} / \mathrm{cm}^{2}, \mathrm{FF}=41.63 \%$, efficiency $\eta=4.06 \%$.

Foils with high defect density in the form of surface roughness showed increase in Ga content in the bulk of material. Fill factor that is the measure of squareness of I-V curve also decreased with increase in defect density. Efficiency showed decreasing trend with increasing in surface roughness. The loss in efficiency was attributed to surface roughness of the substrate, increase in Ga content in the bulk of the material and decrease in fill factor.

The solar efficiency of a photovoltaic system depends critically on the spectral distribution of the radiation. At AM 0 the solar spectrum has $1353 \mathrm{~W} / \mathrm{m}^{2}$ value. At PV Materials Laboratory of FSEC, the proposed efficiency at AM 0 to be obtained is in the range of 10 to $15 \%$. Table I provides the projected specific power in W/Kg of flexible metallic substrate at AM 0 for 10 and $15 \%$ efficient CIGS2 solar cells.

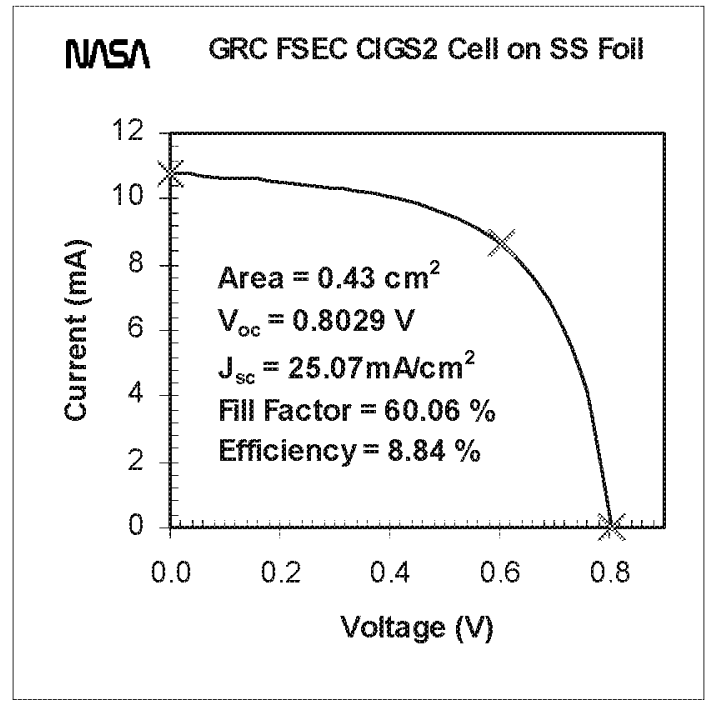

Figure 10. IxV curve of CIGS2 thin film solar cell.

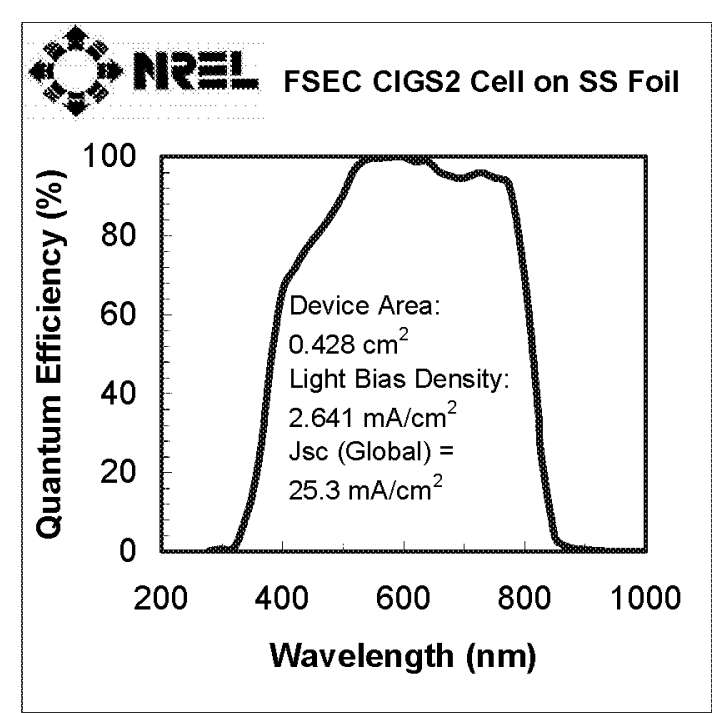

Figure 11. QE curve of CIGS2 thin film solar cell. 


\subsection{LARGE-AREA, DUAL-CHAMBER MAGNETRON-SPUTTERING AND SULFURIZATION SYSTEMS}

Earlier, the substrate size was limited to 1" $\times 1$ ". A large-area, dual-chamber magnetron-sputtering unit has been fabricated recently. The chambers are equipped with cryopumps, two-stage mechanical vacuum pumps, throttled-gate valves, mass-flow controllers for argon and oxygen, and convectron and Bayard-Alpert ionization gauges (Fig.12). A large number of feed-thru ports have been provided to both the chambers for rotation and electrical feed-thru's. This will permit addition of "in situ" diagnostic tools. Three 4" $x$ 12" DC magnetron sputtering sources have been installed for sputter deposition from molybdenum, indium, and copper, $\mathrm{CuGa}(22 \%)$ or CuGa $(67 \%)$ targets in the larger chamber. Two 4" x 12" RF magnetron sputtering sources have been installed into the smaller chamber for $\mathrm{ZnO}$ and $\mathrm{ZnO}$ : Al bilayer window deposition.

The thickness uniformity along the 12 " dimension is expected to be better than $\pm 2 \%$ over the center width of 5 " and better than $\pm 3 \%$ over the center width of 6 " for linear substrates motion along the 4" dimension. Moreover, the sputtering sources are expected to provide excellent $(>40 \%)$ target utilization. A linear substrate movement set-up has been fabricated for "in line" deposition of molybdenum back contact and $\mathrm{Cu}-\mathrm{Ga} / \mathrm{ln}$ metallic precursors. A four-hearth e-beam source has also been procured for vacuum evaporation of $\mathrm{Ni} / \mathrm{Al}$ contact grids. The vacuum system and chambers were designed at the Florida Solar Energy Center (FSEC). Vacuum chambers were built elsewhere. Complete system was constructed at FSEC. Siemens Solar Industries will be donating a selenization-sulfurization furnace, reactor and control system for preparation of large (4"x4") CIGS2 thin films and solar cells.

\section{CONCLUSION}

Sputtered copper, gallium and indium precursors in the ratio of $\mathrm{Cu} /(\mathrm{In}+\mathrm{Ga}) \sim 1.4$ formed a predominant $\mathrm{Cu}_{11} 1 \mathrm{n}_{9}$ precursor phase, free from inhomogeneous secondary phases. The initial dwell of $120^{\circ} \mathrm{C}$ for 30 minutes was changed to $135^{\circ} \mathrm{C}$ for 25 minutes without $\mathrm{H}_{2} \mathrm{~S}$ gas flow during sulfurization. The binary $\mathrm{Cu}_{11} \mathrm{In}_{\mathrm{g}}$ precursor phase reacted in $\mathrm{H}_{2} \mathrm{~S}$ : Ar gas environment to form a good crystalline pseudo-quaternary phase of CIGS2 film. After etching in KCN, CIGS2 films became stoichiometric, regardless of the ratio of $\mathrm{Cu} /(\mathrm{In}+\mathrm{Ga})$ of unetched film. CIGS2 films grew with (112) texture of chalcopyrite structure. The compositional

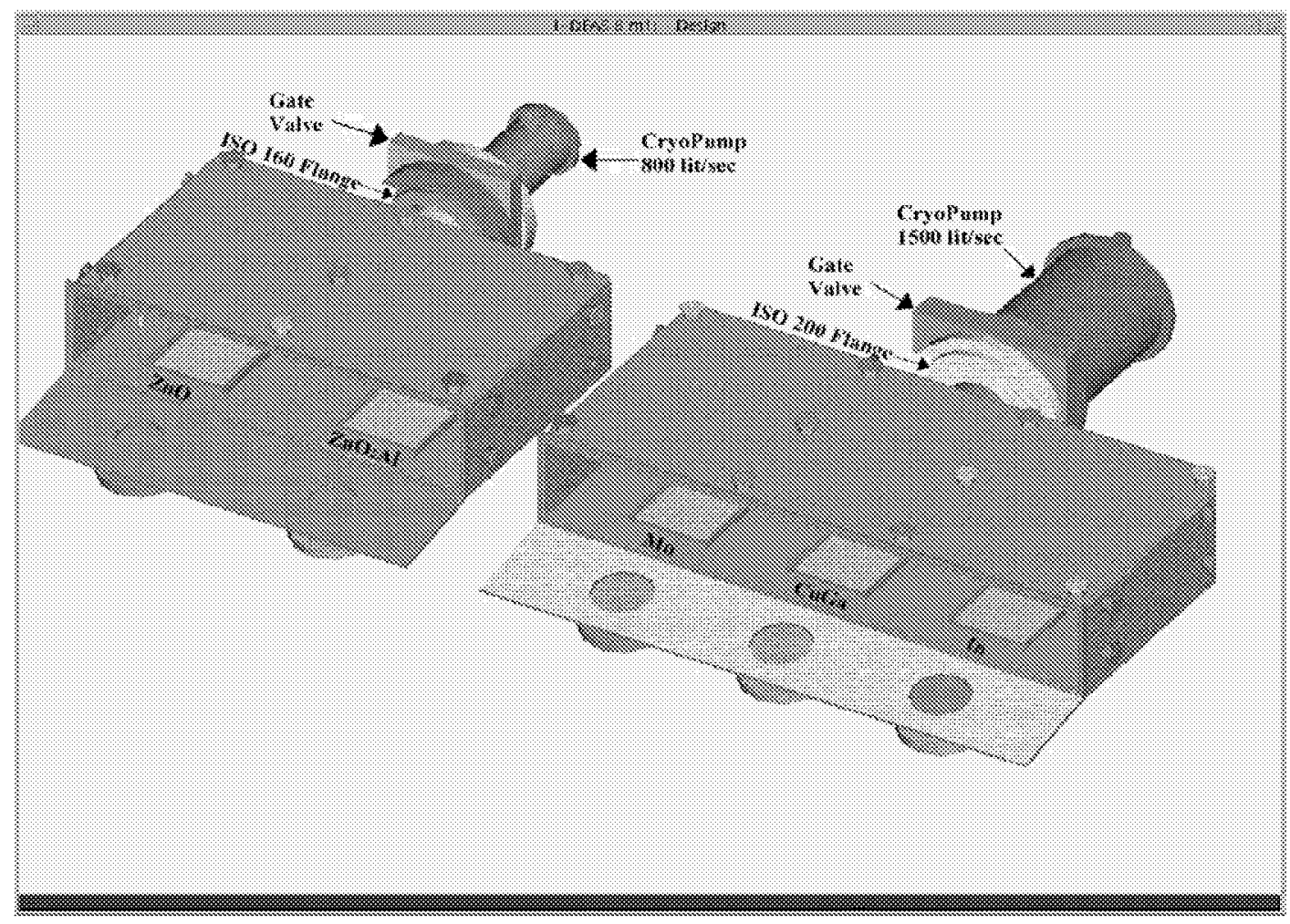

Figure 12. Large-area, dual-chamber magnetron-sputtering unit. 
gradient in Ga content created localized Ga -poor phase in the electrical active part of the device and in the bulk of the film, and highly Ga-rich phase near the back contact. The band-gap of this film was narrow at the surface and gradually widened towards back contact leading to formation of back surface field. This built-in back surface electric field was expected to improve the solar cell performance $[9,10]$.

PV parameters of a CIGS2 solar cell on $127 \mu \mathrm{m}$ thick SS flexible foil measured under AM 0 conditions at the NASA GRC were: $\mathrm{V}_{\mathrm{oc}}=802.9 \mathrm{mV}, \mathrm{J}_{\mathrm{sc}}=25.07 \mathrm{~mA} / \mathrm{cm}^{2}, \mathrm{FF}=60.06 \%$, and efficiency $0=8.84 \%$. For this cell, AM 1.5 PV parameters measured at NREL were: $\mathrm{V}_{\mathrm{oc}}=788 \mathrm{mV}, \mathrm{J}_{\mathrm{sc}}=19.78 \mathrm{~mA} / \mathrm{cm}^{2}, \mathrm{FF}=59.44 \%, 0=$ $9.26 \%$. Quantum efficiency curve showed a sharp QE cutoff equivalent to CIGS2 bandgap of $\sim 1.50 \mathrm{eV}$, fairly close to the optimum value for efficient AMO PV conversion in the space. PV parameters for cell fabricated on $20 \mu \mathrm{m}$ thick SS foil measured at NREL under AM 1.5 conditions were: $\mathrm{Voc}=740 \mathrm{mV}, \mathrm{Jsc}=13.129 \mathrm{~mA} / \mathrm{cm}^{2}$, $\mathrm{FF}=41.63 \%$, efficiency $\eta=4.06 \%$. Foils with high defect density in the form of surface roughness showed increase in $\mathrm{Ga}$ content in the bulk of material. Fill factor that is the measure of squareness of I-V curve also decreased with increase in defect density. Efficiency showed decreasing trend with increasing in surface roughness. The loss in efficiency was attributed to surface roughness of the substrate, increase in Ga content in the bulk of the material and decrease in fill factor.

With the construction of large-area, dual-chamber magnetron-sputtering unit, samples having thickness uniformity of $\pm 2 \%$ over the central 5 " width and $\pm 3 \%$ over the central 6 " width would be fabricated.

\section{REFERENCES}

1. S. G. Bailey and D. J. Flood, Space Photovoltaics, Prog. Photovolt. Res. Appl. 6, 1-14, (1998).

2. E. L. Ralph, and T. W. Woike, Solar Cell Array System Trades - Present and Future, Proceedings of $37^{\text {th }}$ American Institute of Aeronautics and Astronautics Aerospace Sciences Meeting and Exhibit pp. 17,1999

3. J. Tringe, J. Merrill, and K. Reinhardt, Proc. $28^{\text {th }}$ IEEE Photovoltaic Specialists Conference, Anchorage, Alaska, AK, 2000.

4. Takuya Satoh, Yasuhiro Hashimoto, Shin-ichi Shimakawa, Shigeo Hayashi and Takayuki Negami, CIGS solar cells on flexible stainless steel substrates, $28^{\text {th }}$ IEEE Photovoltaic Specialists Conference, Anchorage, AK., pp. 567- 570, 2000.

5. R. Scheer, H. J. Lewerenz, Formation of secondary phases in evaporated CulnS2 thin films. I.A Surface stoichiometry and phase segregation, J. Vac. Sci. Technology A 13(4), pp. 1924-1929, 1995.

6. R. W. Miles, K. T. Ramakrishna Reddy, and I. Forbes, Synthesis of CulnS ${ }_{2}$ from magnetron sputtered $\mathrm{Cu} / \mathrm{In}$ bilayers for use in thin film solar cells, $2^{\text {nd }}$ WCEPVSEC, Vienna, $496-499$, 1998.J. Klaer, J.

7. A. Neisser, I. Hengel, R. Klenk Th. W. Matthes, J. A. García, A. P. Rodríguez, A. R. Rodríguez, M. Ch. Stenier, Effect of $\mathrm{Ga}$ incorporation in sequentially prepared CulnS $_{2}$ thin film absorbers, Solar Energy Materials and Solar Cells 67, pp. 97-104, 2001.

8. Neelkanth G. Dhere, Shashank R. Kulkarni, Sanjay S. Chavan and Shantinath R. Ghongadi, Cu (In, Ga) $\mathrm{S}_{2}$ thin - film solar cells prepared by $\mathrm{H}_{2} \mathrm{~S}$ sulfurization of CuGa-In precursor, SPRAT XVI, Cleveland $\mathrm{OH}, 1999$.

9. Neelkanth G. Dhere, Shashank R. Kulkarni and Shantinath R. Ghongadi, PV characterization of CIGS2 thin film solar cells, $28^{\text {th }}$ IEEE Photovoltaic Specialists Conference, Anchorage, AK., pp. 1046, 2000.

10. Neelkanth G. Dhere, Shashank R. Kulkarni and Pamela K. Johnson, Bandgap optimization of CIGS2 space solar cells, Proc. $16^{\text {th }}$ European Photovoltaic Solar Energy Conference, Glasgow UK, pp. 1-4, 2000.

11. Bruns, R. Henninger, K. Topper, R. Klenk, K. Ellmer and D. Braunig, A tolerant two step process for efficient CulnS ${ }_{2}$ solar cell, $2^{\text {nd }}$ WCEPVSEC, Vienna, 537- 540, 1998.

12. H. W. Schock, Polycrystalline compound semiconductor thin films in solar cells, Springer Proceedings in physics, Vol. 35, pp. $246-256,1989$. 